\title{
Pemilihan Sarana Penerimaan Tenaga Kerja Pada LPK Bintang Mandiri Menggunakan Metode Analytical Hierarchy Process
}

\author{
Olivia Gadisa ${ }^{1}$, Sri Muryani ${ }^{2}$ \\ ${ }^{1,2}$ Sekolah Tinggi Manajemen Informatika dan Komputer Nusa Mandiri \\ E-mail: ooliviagad@gmail.com \\ E-mail: sri.smy@nusamandiri.ac.id

\begin{tabular}{ccc}
\hline Diterima & Direvisi & Disetujui \\
$04-03-2021$ & $18-03-2021$ & $24-03-2021$ \\
\hline
\end{tabular}

\begin{abstract}
Abstrak - LPK Bintang Mandiri merupakan salah satu lembaga jasa penyaluran kerja yang kini mulai berkembang didaerah Jabodetabek. LPK Bintang Mandiri hadir dengan konsep memberikan service terbaik kepada klien dan mencari Sumber Daya Manusia yang kompeten dalam bidang tersebut. Hal ini sangat tepat untuk menumbuhkan strategi dengan sistem kepercayaan. Untuk dapat memilih tenaga kerja yang sesuai dapat digunakan beberapa strategi pada tahap seleksi, strategi ini dapat dilakukan baik secara internal maupun external. Ada beragam sarana penerimaan tenaga kerja secara online, banyak jenis website penerimaan tenaga kerja yang menawarkan berbagai macam fasilitas menu untuk mempermudah proses seleksi. Karena banyaknya website tersebut maka dibuatlah sebuah perbandingan untuk memilih sarana penerimaan tenaga kerja yang efektif dan efisien bagi staff bagian proses seleksi tenaga kerja. Dengan adanya kasus tersebut maka dibuatlah sebuah penelitian dengan menggunakan metode Analitycal Hierarchy Process (AHP). AHP adalah metode penelitian untuk pengambilan suatu keputusan dengan menggunakan hierarki dan melakukan perbandingan pada setiap kriteria dan alternatif yang menjadi pertimbangan dalam pengambilan keputusan.
\end{abstract}

Kata Kunci: Sistem Pendukung Keputusan, Pemilihan Sarana Penerimaan, AHP

Abstract - LPK Bintang Mandiri is one of the work delivery service institutions that is now starting to develop in the Jabodetabek area. LPK Bintang Mandiri comes with the concept of providing the best service to clients and looking for competent Human Resources in this field. This is very appropriate to cultivate a strategy with a belief system. To be able to select the appropriate workforce, several strategies can be used at the selection stage, these strategies can be carried out both internally and externally. There are various online recruitment facilities, many types of recruitment websites that offer various menu facilities to simplify the selection process. Due to the large number of sites, a comparison was made to select an effective and efficient means of recruitment for staff in the labor selection process. With this case, a study was made using the Analytical Hierarchy Process (AHP) method. AHP is a research method for making a decision by using a hierarchy and making comparisons on each criterion and alternative that is considered in decision making.

Keywords: Decision Support System, Selection of Reception Facilities, AHP

\section{PENDAHULUAN}

Proses penerimaan calon karyawan merupakan tahap strategis untuk mengidentifikasi tenaga kerja yang tepat. Pentingnya manajemen Sumber Daya Manusia khususnya dalam bidang penerimaan merupakan pengaruh yang sangat besar bagi perusahaan dalam bidang jasa penyaluran tenaga kerja. Untuk dapat memilih tenaga kerja yang sesuai dapat digunakan beberapa strategi pada tahap seleksi, strategi ini dapat dilakukan baik secara internal maupun external.
LPK Bintang Mandiri merupakan salah satu lembaga jasa penyaluran kerja yang kini mulai berkembang didaerah Jabodetabek. Oleh karena itu LPK Bintang Mandiri harus mampu bersaing dengan cerdas. Strategi yang digunakan haruslah sesuai dengan format dan konsep dasar dari jasa tersebut. LPK Bintang Mandiri hadir dengan konsep memberikan service terbaik kepada klien dan mencari Sumber Daya Manusia yang kompeten dalam bidang tersebut, hal ini sangat tepat untuk menumbuhkan strategi dengan sistem kepercayaan. 
Menurut (Yanuarti 2019) Seleksi merupakan proses untuk memutuskan karyawan yang tepat dari sekumpulan calon karyawan yang dapat melalui proses perekrutan, baik perekrutan internal maupun eksternal.

Banyaknya sarana yang dapat digunakan untuk proses penerimaan calon tenaga kerja, membuat staff penerimaan atau staff rekrutmen merasa bingung memilih sarana yang sesuai dengan perusahaan. Ada beberapa sarana penerimaan calon karyawan yang tidak sesuai, seperti keterlambatan pengiriman data yang menghasilkan penumpukan data calon tenaga kerja.

Karena maraknya sarana penerimaan calon tenaga kerja saat ini, maka penelitian ini mengambil tiga sampel sarana yaitu OLX, Facebook dan Whatsapp. Maka dari itu dibuatlah pengujian untuk meneliti sarana penerimaan calon tenaga kerja yang sesuai dan banyak diminati oleh semua kalangan.

Berdasarkan latar belakang yang telah diuraikan sebelumnya, terdapat beberapa permasalahan, yaitu bagaimana cara yang dilakukan untuk menentukan pemilihan sarana penerimaan tenaga kerja dengan metode Analitycal Hierarchy Process, Sarana penerimaan tenaga kerja apa saja yang direkomendasikan, Kriteria apa saja yang ditetapkan dalam Sistem Pendukung Keputusan pemilihan sarana penerimaan tenaga kerja pada LPK Bintang Mandiri.

\section{METODE PENELITIAN}

Ada banyak metode serta model dalam sistem pendukung keputusan tetapi dalam penelitian ini digunakan metode Analyctical Hierchy Proces) atau sering disingkat dengan metode AHP. Metode ini digunakan karena dianggap lebih cocok untuk memilih efektifitas sarana penerimaan calon tenaga kerja yang akan diteliti.

A. Observasi

Dalam tahap ini peneliti melakukan pengamatan langsung terhadap proses penerimaan calon tenaga kerja yang dilakukan oleh karyawan. Observasi ini berlangsung selama \pm 1 Bulan

B. Wawancara

Metode ini dilakukan dengan sesi tanya jawab antara peneliti dengan karyawan yang melakukan proses penerimaan calon tenaga kerja, guna mendapatkan informasi mengenai sistem penerimaan sumber daya manusia. Kegiatan wawancara ini dilakukan selama \pm 2 Minggu.

C. Studi Pustaka

Metode studi pustaka dilakukan dengan mengumpulkan beberapa data dan informasi dengan cara membaca buku-buku referensi dan sumber-sumber internet yang dapat dijadikan sebagai acuan dalam penelitian.

Metode Analyctical Hierarchy Process (AHP) merupakan metode yang sifatnya persepsional, artinya tingkat kepentingan dari suatu kriteria alternatif tergantung sudut pandang atau perspektif seseorang dalam menilainya (Dicky, 2017)

AHP sering digunakan sebagai metode pemecahan masalah dibanding dengan metode yang lain karena alasan-alasan sebagai berikut (Sutrisno,2017) :

1. Struktur yang berhirarki, sebagai konsekuesi dari kriteria yang dipilih, sampai pada subkriteria yang paling dalam.

2. Memperhitungkan validitas sampai dengan batas toleransi inkonsistensi berbagai kriteria dan alternatif yang dipilih oleh pengambil keputusan.

Penentuan jumlah dan isi butir pernyataan dalam kuesioner dilakukan dengan mengacu pada definisi masing-masing variabel penelitian. Data dari pengguna kuesioner yang telah disebarkan dan kemudian diisi oleh para responden sebagai acuan untuk pengolahan data digunakan dalam penelitian.

Populasi dalam penelitian adalah para responden yang menggunakan dan sering melakukan seleksi tenaga kerja secara online di sebuah sarana melamar pekerjaan yang telah melakukan pengisian kuesioner.

Sampel adalah bagian dari jumlah dan karakteristik yang dimiliki oleh populasi tersebut (Sugiyono, 2017)

Dalam analisa ini menggunakan analisis data kualitatif dan analisis data kuantitatif. Analisis data kualitatif adalah analisis data yang digunakan apabila data yang terkumpul tidak dapat diangkat, dalam artian hanya berupa uraian kata menjadi suatu masalah. Sedangkan analisis data kuantitatif adalah analisis data yang digunakan apabila kesimpulan yang diperoleh berupa angka-angka dan dalam perhitungan digunakan rumus-rumus yang berkaitan dengan analisis penelitian. Dalam hal ini akan dipergunakan analisis AHP (Analytical Hierarchy Process).

\section{HASIL DAN PEMBAHASAN}

\section{Analisa Data}

Kuesioner yang telah disebarkan kepada responden Staff Rekrutmen Online di LPK Bintang Mandiri. Penyebaran kuesioner dilakukan secara langsung kepada responden. Penyebaran kuesioner dimulai pada bulan Desember 2020. Untuk mempermudah pengisian dan pengolahan data, maka dibuatklah kriteria dan alternatif pada pemilihan situs web penerimaan tenaga kerja pada LPK Bintang Mandiri. Berikut ini merupakan kriteria dan alternatif yang digunakan dalam penelitian. Kriteria dalam penelitian ini adalah

1. Kemudahan

Kemudahan dalam artian mudah dalam menjalankan suatu aplikasi dan juga mudah dalam mengumpulkan dan mengorganisir data pelamar kerja. 


\section{Efektifitas}

Efektifitas adalah tercapainya suatu tujuan dengan maksimal sesuai dengan yang diharapakan dan telah ditentukan sebelumnya.

\section{Kualitas}

Kualitas adalah tingkatan baik buruk derajat sesuatu. Istilah ini banyak digunakan dalam bisnis, rekayasa dan manufaktur dalam kaitannya dengan teknik dan konsep untuk memperbaiki kualitas produk atau jasa yang dihasilkan.

Sedangkan altermatif yang bisa dijadikan pilihan adalah Facebook, Whatsapp, Olx

\section{Struktur Hierarki}

Berdasarkan kriteria dan alternatif yang telah diambil, maka disusunlah dalam sebuah bentuk hierarki agar lebih mempermudah dalam pengolahan data. Berikut adalah hierarki untuk pengambilan keputusan pemilihan penerimaan calon tenaga kerja secara online.

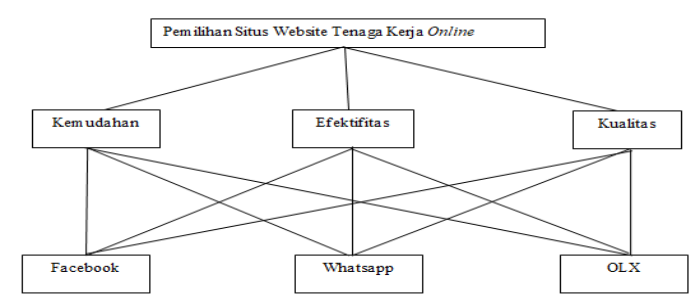

Sumber: Hasil Penelitian (2020)

Gambar 1. Struktur Hirarki

\section{Matriks Perbandingan}

Dari hasil pengisian kuesioner yang telah disebarkan kepada responden, kemudian dibuat dalam bentuk matriks perbandingan berpasangan untuk mendapatkan bobot dari kriteria masingmasing. Untuk lebih mempermudah dalam perhitungannya, maka dibuatlah dalam bentuk tabel dari setiap elemennya didesimalkan berdasarkan matriks perbandingan yang telah dibuat maka datadata tersebut dapat diolah untuk memperoleh indeks konsistensi dan rasio konsistensi.

Dengan demikian hasil matriks berpasangan untuk masing-masing kriteria dan alternatif yang dibuat adalah dapat dilihat dari tabel-tabel dibawah ini.

Kriteria Utama Matriks berpasangan untuk kriteria utama dari olah data kuesioner maka menghasilkan tabel sebagai berikut:

Tabel 1. Matriks Perbandingan Kriteria Utama

\begin{tabular}{|l|l|l|l|}
\hline \multicolumn{4}{|c|}{ Rekapitulasi } \\
\hline KRITERIA & Mudah & Efektif & Kualitas \\
\hline Mudah & 1,00 & 4,22 & 1,65 \\
\hline Efektif & 0,24 & 1,00 & 0,30 \\
\hline Kualitas & 0,61 & 3,30 & 1,00 \\
\hline Jumlah & 1,84 & 8,52 & 2,95 \\
\hline
\end{tabular}

Sumber: Hasil Penelitian (2020)
Dengan unsur-unsur pada tiap kolom dibagi dengan jumlah kolom yang bersangkutan, akan diperoleh bobot relatif yang dinormalkan. Nilai vector eigen dihasilkan dari rata-rata bobot relative untuk setiap baris.

Tabel 2. Matriks Faktor Pembobotan Hierarki semua kriteria yang dinormalkan

\begin{tabular}{|l|l|l|l|l|l|}
\hline \multicolumn{7}{|c|}{ Normalisasi } \\
\hline KRITERIA & FB & WA & OLX & Jumlah & $\begin{array}{l}\text { Rata- } \\
\text { rata }\end{array}$ \\
\hline FB & 0,32 & 0,34 & 0,27 & 0,93 & 0,31 \\
\hline WA & 0,46 & 0,49 & 0,54 & 1,49 & 0,50 \\
\hline OLX & 0,22 & 0,17 & 0,19 & 0,58 & 0,19 \\
\hline Jumlah & 1,00 & 1,00 & 1,00 & 3,00 & 1,00 \\
\hline
\end{tabular}

Sumber: Hasil Penelitian (2020)

Selanjutnya Nilai vector eigen dikalikan dengan matriks semula, menghasilkan nilai untuk tiap baris, yang selanjutnya setiap nilai dibagi kembali dengan vector yang bersangkutan. Nilai rata-rata dari hasil pembagian ini merupakan principal eigen value maksimum ( $\lambda$ maks).

$\lambda_{\text {Max }}=3.009$

Karena matriks berordo 3 (yakni terdiri dari 3 kriteria utama), nilai indeks konsistensi (CI) yang di peroleh:

$\mathrm{CI}=\frac{\lambda_{\operatorname{Max}}-n}{n-1}=\frac{3.009-3}{3-1}=\frac{(0.009)}{2}=0.005$

Matriks terdiri dari 3 kriteria maka nilai RI yang di dapat adalah 0.58

Jika $n=3, \mathrm{RI}=0.58$ maka:

$C R \frac{C I}{I R}=\frac{0.005}{0.58}=0.008$

Karena CR $<0.100$ maka preferensi responden adalah konsisten.

Karena $C R<0,100$ berarti prefensi responden adalah konsisten dari hasil perhitungan pada tabel diatas menunjukan bahwa Kemudahan merupakan yang paling penting bagi pemilihan sarana penerimaan tenaga kerja online dengan nilai bobot 0,53 atau $53 \%$ berikutnya adalah Kualitas dengan nilai bobot 0,35 atau $35 \%$ dan yang terakhir Efektif dengan bobot nilai 0,12 atau $12 \%$.

\section{Kriteria Kemudahan}

Matriks berpasangan untuk kriteria kemudahan dari olah data kuesioner maka menghasilkan tabel sebagai berikut:

Tabel 3. Matriks Perbandingan Kriteria Kemudahan

\begin{tabular}{|c|c|c|c|}
\hline \multicolumn{4}{|c|}{ Rekapitulasi } \\
\hline KRITERIA & FB & WA & OLX \\
\hline FB & 1,00 & 0,69 & 1,44 \\
\hline WA & 1,44 & 1,00 & 2,88 \\
\hline OLX & 0,69 & 0,35 & 1,00 \\
\hline Jumlah & 3,14 & 2,04 & 5,33 \\
\hline
\end{tabular}

Sumber: Hasil Penelitian (2020) 
Dengan unsur-unsur pada tiap kolom dibagi dengan jumlah kolom yang bersangkutan, akan diperoleh bobot relatif yang dinormalkan. Nilai vector eigen dihasilkan dari rata-rata bobot relatif untuk setiap baris.

Tabel 4. Matriks Faktor Pembobotan Hierarki untuk kriteria kemudahan yang dinormalkan

\begin{tabular}{|c|c|c|c|c|c|}
\hline \multicolumn{6}{|l|}{ NORMALISASI } \\
\hline KRITERIA & FB & WA & OLX & Jumlah & $\begin{array}{c}\text { Rata- } \\
\text { rata }\end{array}$ \\
\hline FB & 0,32 & 0,34 & 0,27 & 0,93 & 0,31 \\
\hline WA & 0,46 & 0,49 & 0,54 & 1,49 & 0,50 \\
\hline OLX & 0,22 & 0,17 & 0,19 & 0,58 & 0,19 \\
\hline Jumlah & $\mathbf{1 , 0 0}$ & $\mathbf{1 , 0 0}$ & $\mathbf{1 , 0 0}$ & 3,00 & 1,00 \\
\hline
\end{tabular}

Sumber: Hasil Penelitian (2020)

Selanjutnya Nilai vector eigen dikalikan dengan matriks semula, menghasilkan nilai untuk tiap baris, yang selanjutnya setiap nilai dibagi kembali dengan vector yang bersangkutan. Nilai rata-rata dari hasil pembagian ini merupakan principal eigen value maksimum ( $\lambda$ maks).

$\lambda_{\text {Max }}=3.014$

Karena matriks berordo 3 (yakni terdiri dari 3 kriteria utama), nilai indeks konsistensi (CI) yang di peroleh:

$$
\mathrm{CI}=\frac{\lambda_{\operatorname{Max}}-n}{n-1}=\frac{3.014-3}{3-1}=\frac{(0.014)}{2}=0.007
$$

Matriks terdiri dari 3 kriteria maka nilai RI yang di dapat adalah 0.58

Jika $n=3, \mathrm{RI}=0.58$ maka:

$C R \frac{C I}{I R}=\frac{0.007}{0.58}=0.012$

Karena CR $<0.100$ maka preferensi responden adalah konsisten.

Karena $\mathrm{CR}<0,100$ berarti prefensi responden adalah konsisten dari hasil perhitungan pada tabel diatas menunjukan bahwa Whatsapp merupakan yang paling penting bagi pemilihan sarana penerimaan tenaga kerja online dengan nilai bobot 0,50 atau $50 \%$ berikutnya adalah Facebook dengan nilai bobot 0,31 atau $31 \%$ dan yang terakhir OLX dengan bobot nilai 0,19 atau $19 \%$.

\section{Kriteria Efektifitas}

Matriks berpasangan untuk kriteria efektifitas dari olah data kuesioner maka menghasilkan tabel sebagai berikut:

Tabel 5. Matriks Perbandingan Kriteria Efektifitas

\begin{tabular}{|l|l|l|l|}
\hline \multicolumn{4}{|c|}{ Rekapitulasi } \\
\hline KRITERIA & FB & WA & OLX \\
\hline FB & 1,00 & 0,87 & 1,44 \\
\hline WA & 1,14 & 1,00 & 1,44 \\
\hline OLX & 0,69 & 0,69 & 1,00 \\
\hline Jumlah & 2,84 & 2,57 & 3,88 \\
\hline
\end{tabular}

Sumber: Hasil Penelitian (2020)
Dengan unsur-unsur pada tiap kolom dibagi dengan jumlah kolom yang bersangkutan, akan diperoleh bobot relatif yang dinormalkan. Nilai vector eigen dihasilkan dari rata-rata bobot relatif untuk setiap baris. Hasilnya dapat diperoleh pada tabel berikut ini:

Tabel 6. Matriks Faktor Pembobotan Hierarki untuk kriteria efektifitas yang dinormalkan

\begin{tabular}{|l|l|l|l|l|l|}
\hline \multicolumn{7}{|c|}{ Normalisasi } \\
\hline KRITERIA & FB & WA & OLX & Jumlah & $\begin{array}{l}\text { Rata- } \\
\text { rata }\end{array}$ \\
\hline FB & 0,35 & 0,34 & 0,37 & 1,06 & 0,35 \\
\hline WA & 0,40 & 0,39 & 0,37 & 1,16 & 0,39 \\
\hline OLX & 0,24 & 0,27 & 0,26 & 0,77 & 0,26 \\
\hline Jumlah & 1,00 & 1,00 & 1,00 & 3,00 & 1,00 \\
\hline
\end{tabular}

Sumber: Hasil Penelitian (2020)

Selanjutnya Nilai vector eigen dikalikan dengan matriks semula, menghasilkan nilai untuk tiap baris, yang selanjutnya setiap nilai dibagi kembali dengan vector yang bersangkutan. Nilai rata-rata dari hasil pembagian ini merupakan principal eigen value maksimum ( $\lambda$ maks).

$\lambda_{\text {Max }}=3.002$

Karena matriks berordo 3 (yakni terdiri dari 3 kriteria utama), nilai indeks konsistensi (CI) yang di peroleh:

$\mathrm{CI}=\frac{\lambda_{\operatorname{Max}}-n}{n-1}=\frac{3.002-3}{3-1}=\frac{(0.002)}{2}=0.001$

Matriks terdiri dari 3 kriteria maka nilai RI yang di dapat adalah 0.58

Jika $n=3, \mathrm{RI}=0.58$ maka:

$C R \frac{C I}{I R}=\frac{0.001}{0.58}=0.002$

Karena CR $<0.100$ maka preferensi responden adalah konsisten.

Karena CR $<0,100$ berarti prefensi responden adalah konsisten dari hasil perhitungan pada tabel diatas menunjukan bahwa Whatsapp merupakan yang paling penting bagi pemilihan sarana penerimaan tenaga kerja online dengan nilai bobot 0,39 atau $39 \%$ berikutnya adalah Facebook dengan nilai bobot 0,35 atau $35 \%$ dan yang terakhir OLX dengan bobot nilai 0,26 atau $26 \%$.

\section{Kriteria Kualitas}

Matriks berpasangan untuk kriteria kualitas dari olah data kuesioner maka menghasilkan tabel sebagai berikut:

Tabel 7. Matriks Perbandingan Kriteria Kualitas

\begin{tabular}{|l|l|l|l|}
\hline \multicolumn{4}{|c|}{ Rekapitulasi } \\
\hline KRITERIA & FB & WA & OLX \\
\hline FB & 1,00 & 0,33 & 0,44 \\
\hline WA & 3,00 & 1,00 & 1,26 \\
\hline OLX & 2,29 & 0,79 & 1,00 \\
\hline Jumlah & 6,29 & 2,13 & 2,70 \\
\hline
\end{tabular}

Sumber: Hasil Penelitian (2020) 
Dengan unsur-unsur pada tiap kolom dibagi dengan jumlah kolom yang bersangkutan, akan diperoleh bobot relatif yang dinormalkan. Nilai vector eigen dihasilkan dari rata-rata bobot relatif untuk setiap baris.

Tabel 8. Matriks Faktor Pembobotan Hierarki untuk kriteria kualitas yang dinormalkan

\begin{tabular}{|l|l|l|l|l|l|}
\hline \multicolumn{7}{|c|}{ Normalisasi } \\
\hline Kriteria & FB & WA & OLX & Jumlah & $\begin{array}{l}\text { Rata- } \\
\text { rata }\end{array}$ \\
\hline FB & 0,16 & 0,16 & 0,16 & 0,48 & 0,16 \\
\hline WA & 0,48 & 0,47 & 0,47 & 1,41 & 0,47 \\
\hline OLX & 0,36 & 0,37 & 0,37 & 1,11 & 0,37 \\
\hline Jumlah & 1,00 & 1,00 & 1,00 & 3,00 & 1,00 \\
\hline
\end{tabular}

Sumber: Hasil Penelitian (2020)

Selanjutnya Nilai vector eigen dikalikan dengan matriks semula, menghasilkan nilai untuk tiap baris, yang selanjutnya setiap nilai dibagi kembali dengan vector yang bersangkutan. Nilai rata-rata dari hasil pembagian ini merupakan principal eigen value maksimum ( $\lambda$ maks).

$\lambda_{\text {Max }}=3.000$

Karena matriks berordo 3 (yakni terdiri dari 3 kriteria utama), nilai indeks konsistensi (CI) yang di peroleh:

$$
\mathrm{CI}=\frac{\lambda_{\mathrm{Max}}-n}{n-1}=\frac{3.000-3}{3-1}=\frac{(0.000)}{2}=0.000
$$

Matriks terdiri dari 3 kriteria maka nilai RI yang di dapat adalah 0.58

Jika $n=3, \mathrm{RI}=0.58$ maka:

$C R \frac{C I}{I R}=\frac{0.000}{0.58}=0.000$

Karena CR $<0.100$ maka preferensi responden adalah konsisten.

Karena CR $<0,100$ berarti prefensi responden adalah konsisten dari hasil perhitungan pada tabel diatas menunjukan bahwa Whatsapp merupakan yang paling penting bagi pemilihan sarana penerimaan tenaga kerja online dengan nilai bobot 0,47 atau $47 \%$ berikutnya adalah OLX dengan nilai bobot 0,37 atau $37 \%$ dan yang terakhir Facebook dengan bobot nilai 0,16 atau $16 \%$.

\section{Perhitungan Total Rangking}

Dalam perhitungan total rangking yang harus dilakukan adalah dengan mengalikan rata-rata dari kriteria utama dengan rata-rata dari alternatif maka hasil yang didapat sebagai berikut:

Tabel 9. Perangkingan

\begin{tabular}{|l|l|l|}
\hline \multicolumn{3}{|c|}{ Perangkingan } \\
\hline Alternatif & Hasil & Peringkat \\
\hline FB & 0,2621 & 3 \\
\hline WA & 0,4755 & 1 \\
\hline OLX & 0,2624 & 2 \\
\hline
\end{tabular}

Sumber: Hasil Penelitian (2020)
Dari hasil preferensi diatas maka website yang mendapat perolehan tertinggi adalah Whatsapp dengan hasil preferensi sebanyak 0.4755 disusul OLX di peringkat kedua dengan hasil preferensi sebanyak 0.2624. Sedangkan Facebook berada di peringkat ketiga dengan hasil preferensi sebanyak 0.2621 .

\section{Hasil Implementasi dengan aplikasi Expert Choice}

Setelah melakukan perhitungan data secara manual maka selanjutnya adalah menginput datadata kuesioner tersebut menggunakan aplikasi Expert Choice Versi 11 yang hasilnya dapat dilihat sebagai berikut:

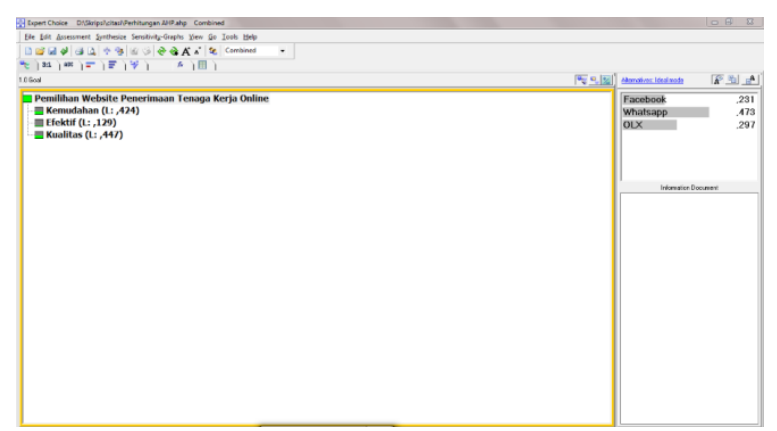

Sumber: Hasil Penelitian (2020)

Gambar 2. Hasil Input Data Responden Kriteria Utama.

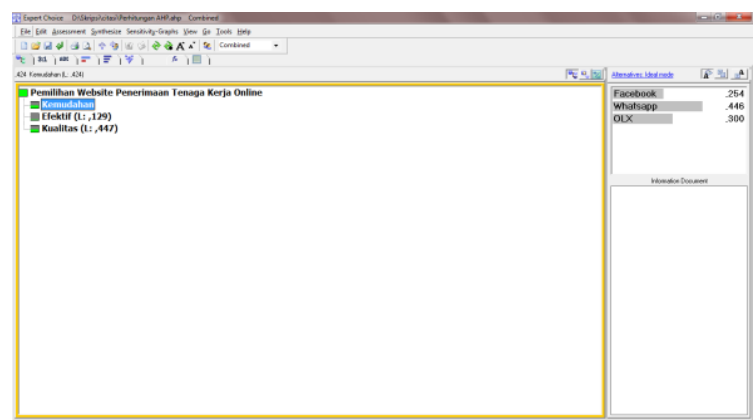

Sumber: Hasil Penelitian (2020)

Gambar 3. Hasil Input Kriteria Kemudahan.

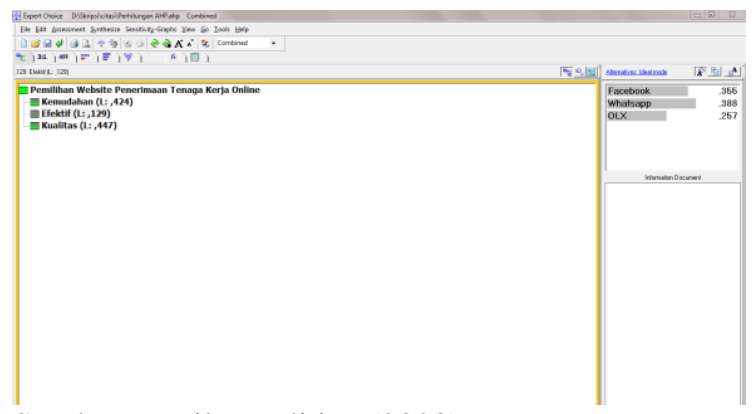

Sumber: Hasil Penelitian (2020)

Gambar 4. Hasil Input Kriteria Efektif 


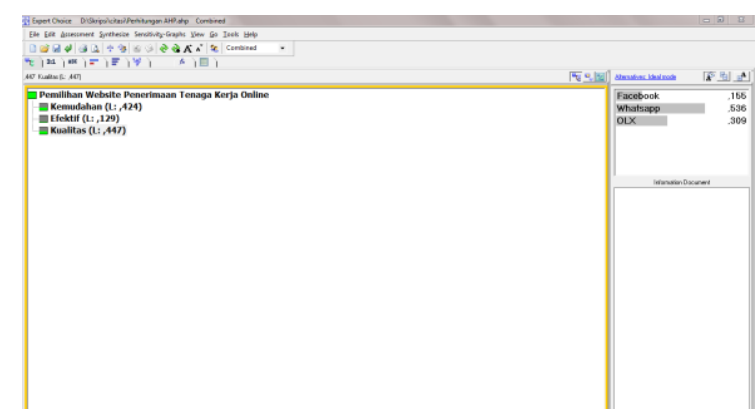

Sumber: Hasil Penelitian (2020)

Gambar 5. Hasil Input Kriteria Kualitas

Inconsistency Ratio Expert Choice dapat dilihat pada gambar berikut:

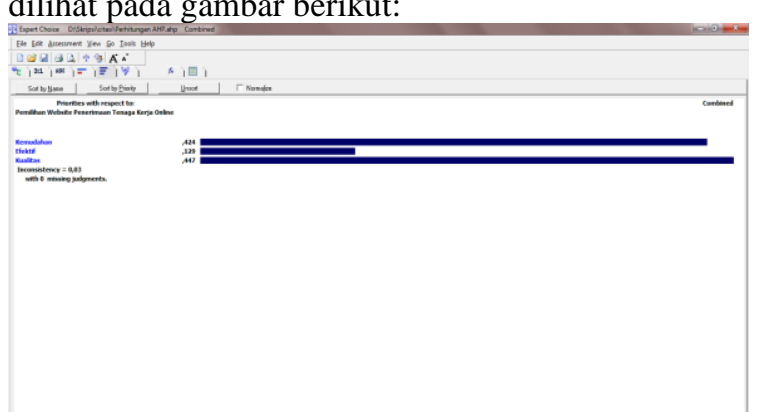

Sumber: Hasil Penelitian (2020)

Gambar 6. Inconsistency Ratio Kriteria Utama.

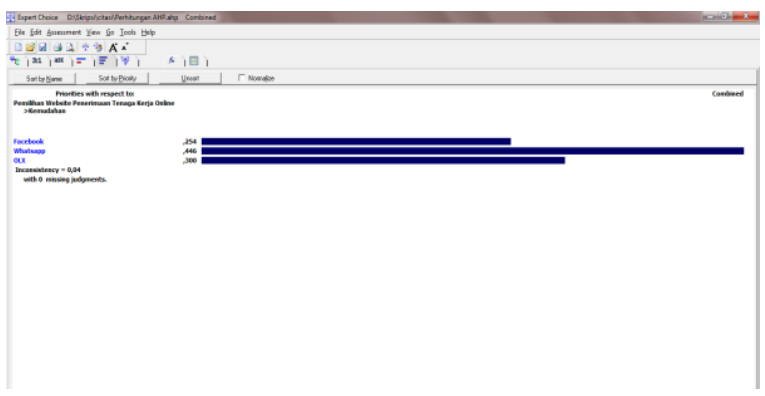

Sumber: Hasil Penelitian (2020)

Gambar 7. Inconsistency Ratio Kriteria Kemudahan.

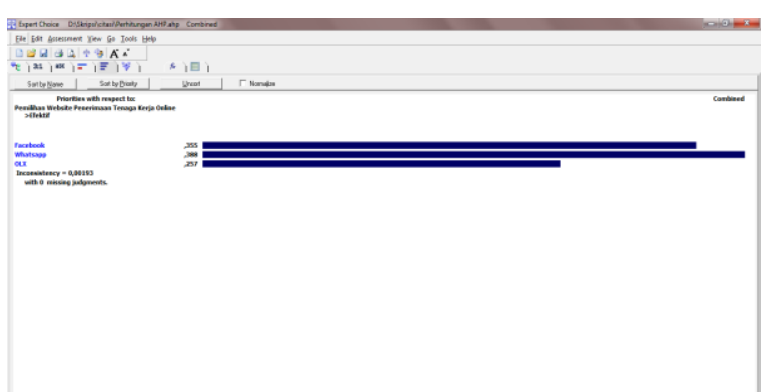

Sumber: Hasil Penelitian (2020)

Gambar 8. Inconsistency Ratio Kriteria Efektif.

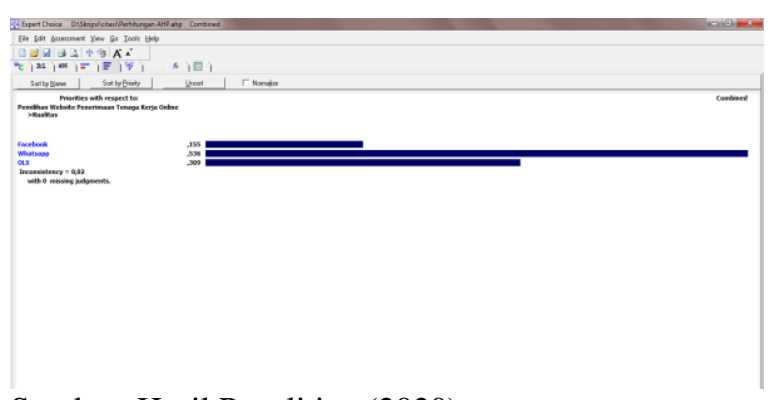

Sumber: Hasil Penelitian (2020)

Gambar 9. Inconsistency Ratio Kriteria Kualitas.

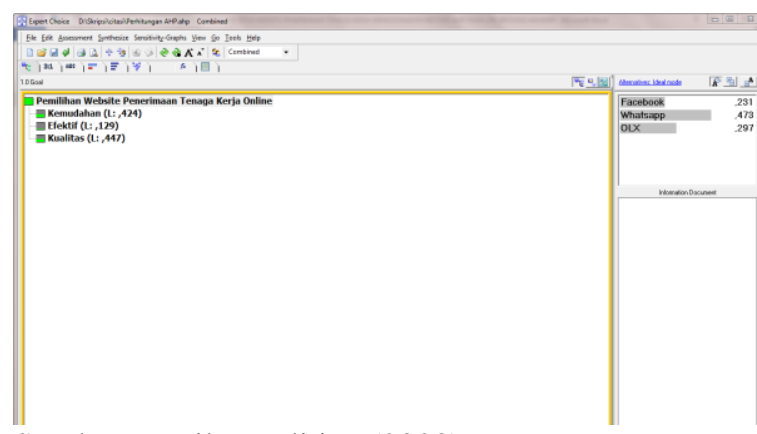

Sumber: Hasil Penelitian (2020)

Gambar 10. Grafik Nilai Akhir

Hasil nilai akhir dengan menggunakan Expert Choice versi 11 diatas maka website yang mendapat perolehan tertinggi adalah Whatsapp dengan hasil preferensi sebanyak 0.4755 disusul OLX di peringkat kedua dengan hasil preferensi sebanyak 0.2624. Sedangkan Facebook berada di peringkat ketiga dengan hasil preferensi sebanyak 0.2621.

\section{KESIMPULAN}

Dalam pemilihan penerimaan tenaga kerja menggunakan metode Analytical Hierarchy Process (AHP) dapat memudahkan para pengguna untuk memilih alternatif pilihan sesuai dengan kebutuhan. Alternative pilihan juga memilih manakah yang paling mudah, efektif dan berkualitas.

Dengan adanya pengolahan data kuesioner tersebut, staff bagian seleksi dapat memperoleh informasi yang tepat mengenai penerimaan tenaga kerja manakah yang harus dipilih.

Dalam pemilihan penerimaan tenaga kerja ini dapat disimpulkan bahwa yang paling diminati staff adalah Whatsapp dengan nilai yang sudah didapat melalui perhitungan yaitu 0,4755 .

\section{REFERENSI}

Fauziah, Konsep Dasar Perancangan Web. 2014. Imron, “Analisa Pengaruh Kualitas Produk Terhadap Kepuasan Konsumen Menggunakan Metode Kuantitatif Pada CV . Meubele Berkah Tangerang," vol. 5, no. 1, hal. 19-28, 2019.

I. Pengetahuan dan D. A. N. T. Komputer, "Seleksi penerimaan karyawan baru menggunakan metode topsis," vol. 4, no. 2, hal. 143-148, 2019. 
Pendidikan, I. Vol, I. Sultan, dan A. Gorontalo, "Proses Pengambilan Keputusan untuk Mengembangkan Mutu Madrasah Herson Anwar," vol. 8, no. April, 2014.

K. Suryana, T, Aplikasi Internet Menggunakan HTML, CSS \& JavaScript. Jakarta, 2014.

M. K. Diana, S.Si., Metode \& Aplikasi Sistem Pendukung Keputusan. 2019.

M. K. Dicky Nofriansyah, S.Kom dan M. S. Prof. Dr. Sarjon Defit, S.Kom, Multi Criteria Decision Making (MCDM) pada Sistem Pendukung Keputusan. 2017.

R. I. Handayani dan A. Muzakir, "SISTEM PENDUKUNG Keputusan Penerimaan Karyawan Dengan Menggunakan Metode Analytical Hierarchy Process ( Ahp ) Studi Kasus : Pt . Virtus Venturama," vol. 14, no. $1,2018$.

R. Ishak, "Sistem Penunjang Keputusan Penerimaan Karyawan Menggunakan Metode Profile Maching dan Analytical Hierachy Process Pada PT . Sunny Collection,” vol. XV, no. 2, 2017.

P. Karyawan dan P. Pt, "Penerapan Metode Ahp Sebagai Penunjang Keputusan," vol. 1, no. 3, 2019.

P. Pelayanan, P. E. Terhadap, M. Studi, K. Di, dan K. Dramaga, "Pengaruh pelayanan pembuatan e-ktp terhadap kepuasan masyarakat studi kasus di kecamatan dramaga kabupaten bogor," no. 1, hal. 8190, 2016. 